progression, Prof. Elliot Smith deals with those truly neurological 'bricks', the thalamus and the hypothalamus, the seats respectively of emotional formulation and effective expression, in the light of their special linkages with the cortex itself, facilitating a "cortico-thalamic circulation" which finds functional expression in an enrichment of concepts by the gains of experience of failure or success in past action. While this broadening of the issues involved in what is now known of the fibre relationships of the cortical and thalamic organs is the outstanding feature of Prof. Elliot Smith's lecture, a paragraph-all too brief-must not be overlooked which records the evident complexity of the neural machinery of the parts involved and proceeds to assert that "it becomes essential to look at the whole issue from a much broader point of view than the mere connexions of thalamus and cerebral cortex". The 'key' word of the sentence is 'connexions' and 'mere' is there to turn it vigorously. Is it justifiable to hope that the self-sufficiency of the neurone is at last to be called in question and that the truly organic character of the brain may be substantiated 'in our time'? Is this not a case where the answer has long been prepared and only awaits the application of the question to reveal its fruitfulness ?

\section{Sir George Buchanan, C.B}

By the retirement of Sir George Buchanan on February 18 from his post as senior medical officer of the Ministry of Health, an association with the public health of Great Britain of nearly forty years is terminated, for Sir George was appointed a medical inspector of the old Local Government Board in 1895. During this period he has accomplished much valuable work over the whole range of public health. In early days he dealt with infectious disease outbreaks, questions of water supply and sewage disposal, housing problems and slum clearance. During the five years 1906-11, he acted as chief inspector of foods, and afterwards was the chief assistant medical officer of the Local Government Board, becoming on the formation of the Ministry of Health its senior medical officer. On the outbreak of War in 1914, Sir George was immediately attached to the Army Sanitary Committee and served on the eastern fronts at Gallipoli and in Macedonia and Mesopotamia, though little mention of the services he rendered there will be found in official records. With the cessation of hostilities commenced his association with the League of Nations. He had been a member of the Health Committee of the League from its foundation, and now became its vice-president, and he also became British representative of the Office International d'Hygiene Publique. In 1919 he was a member of the Poland Typhus Commission instituted by the League of Red Cross Societies, was appointed president of the League of Nations Cancer Commission, and was a member of the League's mission for the public health reorganisation of Greece. In 1926, Sir George was appointed chief British delegate to the International Sanitary Conference. During the last twelve years he has assisted at numerous Government and official investigations.
This bare outline of Sir George Buchanan's activities during his official career suffices to show that he has played a part for which he has earned his country's gratitude.

\section{Dr. Thomas C. Porter}

By the death of Dr. Thomas Porter, for many years science master at Eton College and one of the founders of the (Public Schools) Science Masters' Association, on March 31, aged seventy-three years (Nature, 131, 496, April 8, 1933), science teaching in Great Britain suffered a severe loss. An obituary article in the Journal of the Chemical Society of December 31 stresses Dr. Porter's influence as a teacher. Though he was gifted with remarkable talent, he never allowed himself to specialise. This wide range of interests was the source of inspiration which many of his pupils gained from him. Porter was born at Bristol and was educated at the Grammar School, from which he gained a scholarship in natural science at Exeter College, Oxford, in 1878. In 1885 he was appointed at Eton, and there he taught for forty-eight years. $\mathrm{He}$ was responsible for many improvements and extensions in the teaching of science at the College. Dr. Porter's own investigations covered a wide field. His most serious contribution was on the phenomenon of 'flicker', contributed to the Proceedings of the Royal Society in 1898, 1902 and 1912. He was the first to notice the nonhomogeneity of X-rays (Nature, 54, 149, June 18, 1896). Papers on Newton's rings and the use of flames for enhancing the intensity of sound were published in the Philosophical Magazine.

\section{British Industries Fair}

IT has become almost a stereotyped phrase to say of each British Industries Fair that it is larger and more representative than any that have preceded it. The twentieth British Industries Fair to be held in London and Birmingham on February 19-March 2 maintains this tradition. In the London Section the lighter trades and Empire exhibits will be found at Olympia; while the textiles and clothing and the furniture displays will be at the White City. The Birmingham Section at Castle Bromwich comprises hardware, house equipment, engineering and 'heavy' industries generally. At Castle Bromwich there will also be an out-of-doors exhibition for the display and demonstration of agricultural implements, light railways, and quarrying and road-making plant. The trade groups which have shown the most marked growth, judged by the extent of their exhibits at the Fair, are furniture (the biggest section in the Fair) at the White City, electricity and building at Castle Bromwich, and the following groups at Olympia : Government of India, brush-ware and fancy goods; jewellery, pottery and glass-ware; sports goods; stationery, printing and office equipment, etc.; toys and games; chemicals and druggists' sundries. It is interesting to note that the first British Industries Fair, which began as a War-time experiment in 1915 , consisted of about 5 miles of stands at the Royal Agricultural Hall, Islington, whereas the stands of this twentieth Fair, in 1934, extend to about 32 miles 